\title{
VLADIMIR LITVINOV: AN OBITUARY
}

More than a year has passed since the untimely death of Vladimir Nikolaevich Litvinov. He was a courageous and talented scholar, historian, sociologist and journalist. Unhappily, he was unable to develop his exceptional abilities fully in the very difficult conditions facing any unorthodox scholar in the USSR.

Litvinov was born in Saratov on September 30th, 1930. His father, Nikolai Mikhailovich Litvinov, was an army veterinary surgeon attached to the cavalry units which at that time formed the main vanguard of the Red Army. In 1937 Nikolai Litvinov was arrested in Minsk. Many horses belonging to the cavalry regiments died in an epidemic disease, and Vladimir's father was accused of sabotage. He managed to survive all the traumas of the Stalinist labour camps and was rehabilitated after the Twentieth Congress of the CPSU, only to die a few years later. Vladimir Litvinov's mother, Nina Nikolaevna Litvinova, was educated in both music and medicine. She was a good singer, but after the arrest of her husband she could no longer perform on the stage, and she worked until her death as a nursing sister in Saratov.

Vladimir Litvinov himself was disabled. At the age of ten he lost a leg in an accident. He spent several years in hospital, only managing to finish school in 1951, having attended the school for young workers (an evening school for adults). He did not find his calling immediately. At first he studied law at Saratov University, where he was an excellent student. However he suddenly gave up law and started at the Leningrad Institute of Librarianship, but he soon left this as well. Between 1955 and 1960 he completed a history degree at Saratov University. While still an undergraduate Litvinov began historical research. One of his essays, "On Plekhanov's role in the struggle in the RSDRP against Bogdanov's empiriomonism", was highly regarded by the academic A.M. Deborin. On Deborin's recommendation Litvinov wrote several short articles for the first volume of the Philosophical Encyclopedia (Moscow, 1960). He completed his university 
studies with a first-class degree. The subject of his master's dissertation was the evolution of the social and political ideas of Plekhanov. After leaving university Litvinov worked for two years as head-teacher and teacher of history at the village school of General'skoe in the Saratov region. In 1962 he was accepted as a post-graduate student at Saratov University. By 1965 he had completed his thesis entitled "On the question of the theoretical succession of the raznochinsky and proletarian stages of the liberation movement in Russia". It was an original piece of work, but precisely for this reason, Litvinov was for a long time not allowed to defend it in Saratov. For a while he worked as a teacher in the city of Rybinsk, then he took up sociology and became head of the sociological sector of a works in Saratov. In 1968 Litvinov married and moved to Moscow where he continued to work as a sociologist in a research institute. He was able to defend his thesis at Moscow University where he was awarded the degree of 'candidate of philosophical sciences'. Litvinov published several articles in the field of applied sociology, and the division under his guidance produced some interesting work, which attracted publicity in both scientific and popular Soviet journals. However it was not just increasing ill health which forced Litvinov to leave government service to live on a small invalidity pension. A warm and passionate man, his decision early in 1976 to devote the remainder of his life to the study and rehabilitation of Makhno and the Makhno movement came as a surprise to his friends.

Litvinov had previously studied the rise of anarchist thought and the anarchist movement in Russia and he rated highly Bakunin and Kropotkin, both in terms of their writing and as personalities. In developing his research into the fate of anarchism in Russia, Litvinov naturally could not ignore as important a figure in Russian anarchism as Makhno. The first mention of Makhno in Litvinov's papers dates from 1973. In the years that followed Litvinov undertook a massive project. He examined a great deal of material from the Central State Archive of the October Revolution, he read anything he could obtain in which Makhno's name was so much as mentioned, and he also read the press from the period 1918-22. In 1975 Litvinov made six journeys to Guliai-Pole in order to achieve a better understanding of the events which he was studying. He met there people who still remembered Makhno, some of whom had actually known him. Litvinov found some of Makhno's relations and he tried to enter into correspondence with Makhno's wife, who died in 1980 in Shevchenko. He also found the children of several of the leading figures in the Makhno movement, for example the son of Makhno's H.Q. chief, V.V. Belash. In the local museum at Guliai-Pol he was able to read the memoirs of $V$. Antoni, who had attracted Makhno into the anarchist movement at the turn 
of the century. At the end of the 1970s Litvinov finished the first draft of his book on Makhno. Litvinov knew that it would not be possible to publish it in the USSR. However, what he found most hurtful was that no historian, writer or journalist in Moscow would even read his manuscript. Moreover they began to look upon the author who wanted to write a book about Makhno as someone not quite normal. The name Makhno had become so odious in the USSR, and propaganda had so firmly established in people's minds the one-sided image of Makhno as a bandit and a pogrom-instigator, that any positive references to Makhno and any objective study of the makhnovshchina were seen as deliberate lies. Litvinov was tormented by the knowledge that his great work was redundant.

I was surely the first historian to read Litvinov's work thoroughly, and to discuss its merits and shortcomings with the author. I advised Litvinov to prepare articles and some of the most interesting documents for publication. I also persuaded him to begin working on different subjects. He undertook for me a series of translations from English, a language he had learned with his usual thoroughness. We agreed that he should be paid for this work, and this improved Litvinov's material situation. This gave him the stimulus to continue his work on Makhno and he was particularly pleased by the first publication of his new material in émigré Russianlanguage journals, and in the periodical Iztok. But he was prevented from accomplishing much more by serious illness. Litvinov died of lung cancer on April 18th, 1985. Before his death he sometimes said: "Tell my anarchist friends in Europe about my illness. They will send me the medicines I need". But no-one could help him. The terrible disease affected his brain, and he survived in hospital for only two months. He did not have many friends, but those who knew him well will always remember him as a warm, passionate, talented and good man. 


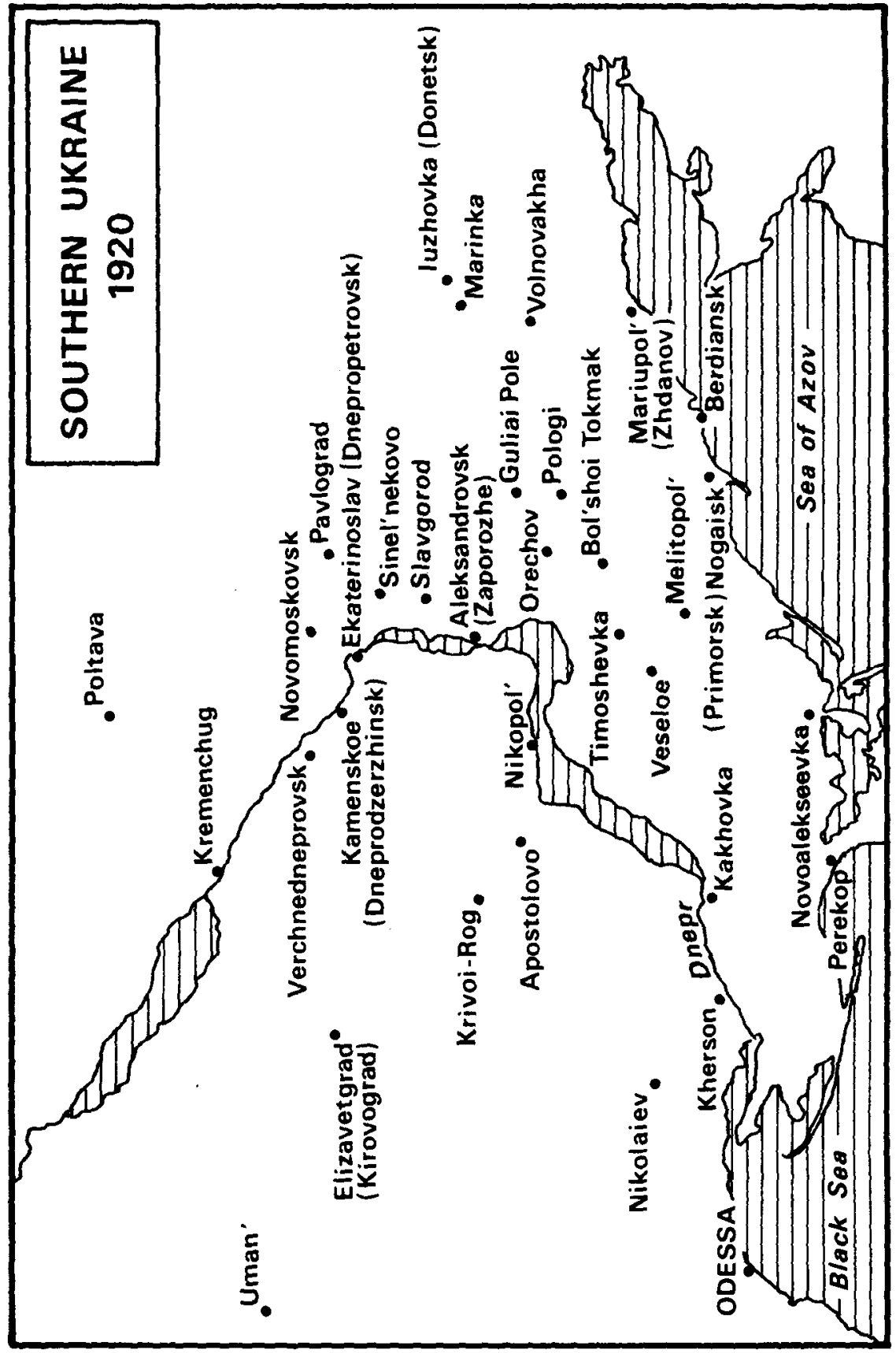

